\title{
Human Immunoglobulin G Stimulates Human Adipocyte Lipogenesis
}

\author{
M.A. Khokher, S. Janah and P. Dandona \\ Metabolic Unit, Department of Chemical Pathology, Royal Free Hospital and School of Medicine, London, UK
}

Summary. The effect of human IgG on human adipocytes has been investigated. Polyclonal IgG prepared from sera of normal subjects, monoclonal IgG from sera of patients with myeloma and IgG harvested from lymphocytes cultures were equally potent in stimulating lipogenesis in human adipocytes. Fe fragments prepared from $\mathrm{IgG}$ fractions also stimulated lipogenesis, whereas Fab fractions were inactive. Pre-incubation of IgG and Fc fragments with $\gamma$-chain specific anti-IgG and anti-Fc antisera neutralised the stimulatory activity of both IgG and Fc fractions. The stimulatory effect of IgG on lipogenesis was demonstrated both on adipocyte suspensions and on adipose tissue. These data demonstrate that human IgG has a specific stimulatory effect on lipogenesis by human adipocytes and that this effect is mediated through the $\mathrm{Fc}$ moiety.

Key words: Adipocyte, insulin, $\operatorname{IgG}, \mathrm{Fc}$, anti-IgG antiserum, protein $A$.
We have shown recently that human immunoglobulin $\mathrm{G}(\mathrm{IgG})$ and $\mathrm{Fc}$ fragments from IgG stimulate lipogenesis in rat adipocytes [1-3]. Since this effect was observed in a heterologous system, its physiological significance is not clear. Hence, we have set out to investigate whether human IgG stimulates lipogenesis in human adipocytes. A stimulatory effect of human IgG on human adipocytes would have implications regarding the physiological role of IgG in the regulation of adipocyte metabolism.

\section{Materials and Methods}

\section{Materials}

Analytical grade $\mathrm{NaCl}, \mathrm{NaOH}, \mathrm{KCl}, \mathrm{CaCl}_{2}, \mathrm{NaH}_{2} \mathrm{PO}_{4}, \mathrm{~N}$-[2-hydroxyethyl] piperazine-N'-2 ethane-sulphonic acid (Hepes) and glucose were obtained from British Drug House, Enfield, UK. Collagenase (Batch no. 4196 CLS 405239, spec. act. 131 units/mg purified from Clostridium Histolycum) was purchased from Millipore Corporation, Freehold, New York, USA. Human serum albumin (crystallised) was obtained from Curewell (India) Ltd., Faridabad (Haryana), India. Monocomponent Actrapid porcine insulin (Novo, Copenhagen, Denmark) was used in all experiments requiring insulin. $\gamma$-chain specific anti-IgG antisera were obtained from Dako-Immunoglobulins, Denmark, and Hoechst, Hounslow, UK. Protein A-sepharose CL-4B and DEAE cellulose were obtained from Pharmacia Fine Chemicals, Uppsala, Sweden. Commercial $\alpha, \beta$, and $\gamma$ globulins and immunoglobulin $\mathrm{G}$ fractions were obtained from Sigma Chemicals, Dorset, UK.

Tissue and cells were suspended in buffer containing the following substances (concentrations in $\mathrm{mmol} / \mathrm{l}$ ): $\mathrm{NaCl} 135$; $\mathrm{KCl} 4.8$;
$\mathrm{MgSO}_{4} 1.70 ; \mathrm{CaCl}_{2} 2.5 ; \mathrm{NaH}_{2} \mathrm{PO}_{4} 1.0$ and Hepes $10 . \mathrm{pH}$ was adjusted to 7.4 at $37^{\circ} \mathrm{C}$ with $1 \mathrm{mmol} / 1 \mathrm{NaOH}$. Human albumin was present at $10-50 \mathrm{~g} / 1$.

\section{Preparation of $\operatorname{Ig} G$}

Human IgG was prepared from sera of three normal subjects (IgG concentrations 8-12 g/1) and two patients with IgG myeloma (IgG concentrations 25 and $30 \mathrm{~g} / 1$ ), using protein A-Sepharose CL-4B columns, as described by Bywater [4]. Conditions of isolation, purification, characterisation and neutralisation of $\mathrm{IgG}$ from sera of normal subjects, myeloma sera and from lymphocyte cultures, were as described previously [2]. There was no detectable immunoreactive insulin in the IgG samples thus prepared.

\section{Preparation of Fc and Fab Fragments of Human $\operatorname{Ig} G$}

Purified $\operatorname{IgG}$ was subjected to papain digestion $(1: 100 \mathrm{w} / \mathrm{w})$ in phosphate buffer $(0.1 \mathrm{~mol} / \mathrm{l} ; \mathrm{pH} 7.6)$ at $37^{\circ} \mathrm{C}$ for $24 \mathrm{~h}$, according to the method of Davies et al. [5]. The undigested IgG was adsorbed on a Sephadex G-100 column. The Fc and Fab fragments were separated on a protein A Sepharose CL-4B column. The Fab fragment came through in the void volume, and bound $\mathrm{Fc}$ was eluted with $1 \mathrm{~mol} / 1$ acetic acid, $0.1 \mathrm{~mol} / 1$ glycine- $\mathrm{HCl}$ buffer, $\mathrm{pH} 3.0$. Both $\mathrm{Fc}$ and $\mathrm{Fab}$ fragments were extensively dialysed against $0.9 \%$ saline. $F(a b)_{2}$ fractions were prepared by pepsin digestion following the method described by Baldwin et al. [6].

\section{Neutralisation of IgG with Antisera}

IgG was incubated at $4^{\circ} \mathrm{C}$ for $24 \mathrm{~h}$ with $\gamma$-chain specific antiserum (Dako Immunoglobulins, Denmark) in the following ratios of $\mathrm{IgG}$ to antiserum $(\mathrm{mg} / 1): 10: 1 ; 5: 1 ; 2: 1 ; 1: 0$ and $1: 3$. Fc and Fab fractions were incubated at $4{ }^{\circ} \mathrm{C}$ for $24-\mathrm{h}$ with their appropriate antisera (Hoechst, Hounslow, UK), in the ratio $1: 3 . \mathrm{IgG}$ and $\mathrm{Fc}$ fractions were also incubated at $4{ }^{\circ} \mathrm{C}$ for $24 \mathrm{~h}$ with anti- $\mathrm{Fc}$ and anti-Fab antiserum in the ratio $1: 3(\mathrm{mg} / \mathrm{l})$. 


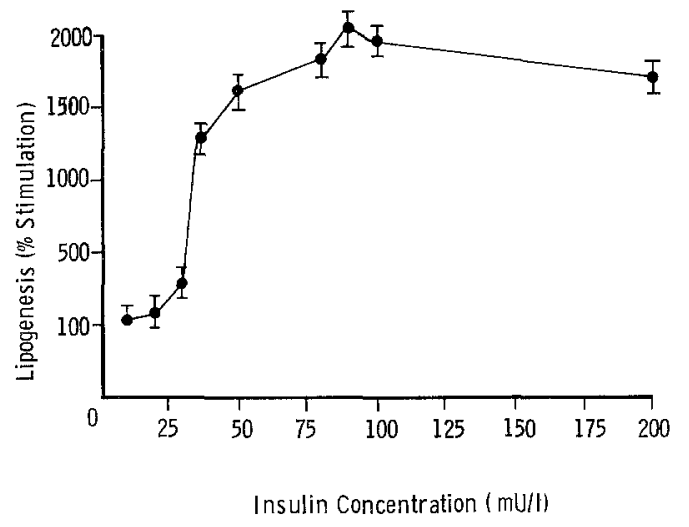

Fig. 1. Effect of porcine monocomponent Actrapid insulin on lipogenesis of human adipocytes. The percentage stimulation for $4 \times 10^{7}$ cells $/ 1$ is shown. Corrected basal counts $120 \mathrm{cpm}$

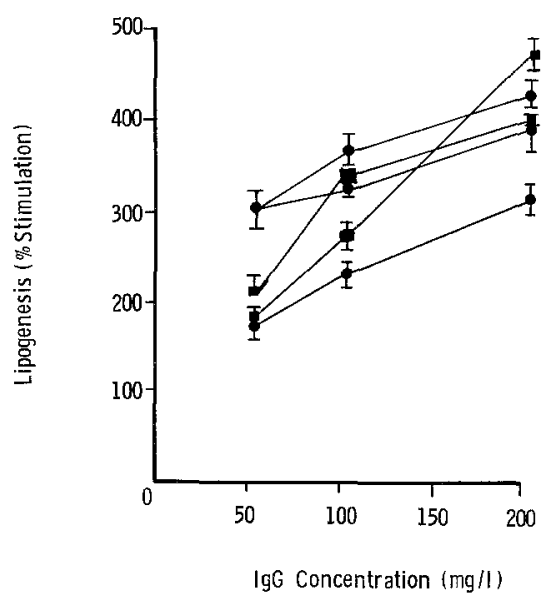

Fig. 2. Effect of human IgG on lipogenesis by human adipocytes $\left(4 \times 10^{7}\right.$ cells $\left./ 1\right)$. control subjects. $\square$ IgG prepared from the sera of two myeloma patients. Corrected basal counts $107 \mathrm{cpm}$

\section{Bioassay}

The human adipocytes were prepared by a method modified from Pedersen et al. [7]. Human adipocytes were obtained from adipose tissue of patients undergoing laparotomy. All patients sampled were in the age range 20-50 years, were not diabetic, and were not on any longterm drug therapy. The tissue specimen (approximately $2 \mathrm{~g}$ ) was excised at the beginning of the operation and placed in Hepes buffer ( $\mathrm{pH} 7.4)$, containing glucose $(0.55 \mathrm{mmol} / \mathrm{l})$ and was brought to the laboratory in a vacuum flask within 15 min of excision. It was immediately washed several times in Hepes buffer and cut into small pieces. The fragments were digested. with collagenase $(0.5 \mathrm{~g} / \mathrm{l})$ in Hepes buffer containing human albumin $(25 \mathrm{~g} / 1)$ and glucose $(0.55 \mathrm{mmol} / 1)$ for $1 \mathrm{~h}$ in a shaking water bath $(120 \mathrm{cycles} / \mathrm{min})$ at $37^{\circ} \mathrm{C}$. The cells were filtered through a nylon mesh and the infranatant was removed. The cells were washed a further four times by flotation; the infranatant was removed and discarded on each occasion. After the final rinse, the adipocytes were removed in Hepes buffer containing human albumin $(50 \mathrm{~g} / \mathrm{l})$ and glucose $(0.55 \mathrm{mmol} / \mathrm{l})$. Aliquots of cells $\left(0.5 \mathrm{ml} ; 4 \times 10^{7}\right.$ cells $\left./ 1\right)$ were transferred into scintillation vials. Test substances were assayed at three concentrations. For each assay, a set of six vials was used. 'Basal controls' consisted of a set of six vials with no test substance added. 'Non-specific background' counts were obtained from another set of six vials, where toluene scintillant was added before incubation. Vials containing test substances, 'basal controls' and 'non-specific background counts' were incubated at $37^{\circ} \mathrm{C}$ for $2 \mathrm{~h}$. The reaction was then stopped by the addition of toluene scintillant, which lysed the adipocytes and extracted the lipid-incorporated radioactivity into the toluene phase. Thus incorporated radioactivity was measured in a $\beta$-scintillation spectrometer $[8,9]$. Antisera used in the experiments were also assayed in view of their high IgG content.

\section{Tissue Experiments}

Human subcutaneous fat obtained as above was chopped into small pieces and incubated in Hepes buffer ( $100 \mathrm{mg}$ adipose tissue $/ \mathrm{ml}$ ) containing human albumin $(50 \mathrm{~g} / \mathrm{l})$ and glucose $(0.55 \mathrm{mmol} / 1)$. [U- $\left.{ }^{14} \mathrm{C}\right]-\mathrm{D}-$ glucose $(0.02 \mu \mathrm{Ci})$ in Hepes buffer $(0.01 \mathrm{ml})$ was added, and the mixture was incubated at $37^{\circ} \mathrm{C}$ for $2 \mathrm{~h}$. Incubation was stopped by the addition of toluene scintillant and homogenisation of the adipose tissue. An aliquot $(200 \mu \mathrm{l})$ from each homogenate was added to another vial and toluene scintillant added (final volume $10 \mathrm{ml}$ ). The radioactivity was measured in a $\beta$-scintillation spectrometer.

\section{Calculations}

The mean of six non-specific background counts was subtracted from the mean counts of test and basal incubates. Percentage stimulation (S) by any test substance was calculated as follows: $\mathrm{S}=\frac{\text { test }- \text { basal } \times 100}{\text { basal }}$.

All results are expressed as percentage enhancement over basal. All statistical comparisons were carried out by the Student's paired ttest.

\section{Results}

The stimulation of adipocyte lipogenesis by insulin was dose dependent over the range 50-100 mU/1 (Fig. 1). Lower concentrations of insulin produced accelerated lipogenesis, but the increase was not consistently statistically significant.

The five samples (three from control subjects; two from myeloma patients) of human IgG prepared by protein A-sepharose chromatography caused a dose dependent (IgG concentration) stimulation of lipogenesis by human adipocytes (Fig. 2). IgG prepared by ammonium sulphate precipitation or DEAE cellulose chromatography [4] were stimulatory, but were less potent than the highly purified IgG prepared by protein Asepharose chromatography (Table 1). The difference in potency could be attributed to the presence of inhibitory impurities since further purification over protein Asepharose enhanced the stimulatory potency of $\mathrm{IgG}$ prepared by the other methods.

Table 2 shows that IgG prepared from supernatants of human lymphocyte cultures was consistently stimulatory to adipocytes, with a potency similar to that of IgG prepared from sera. The stimulatory effect of this IgG was neutralised by $\gamma$-chain specific anti-IgG antiserum.

When insulin and IgG samples were incubated with finely chopped human fat without prior collagenase treatment, lipogenesis was stimulated significantly by both insulin and IgG: $312 \%$ above basal by $200 \mathrm{mU} / 1$ of 
Table 1. Comparison of the stimulatory effects of various purified $\mathrm{IgG}$ fractions on human adipocyte lipogenesis

\begin{tabular}{llll}
\hline \multirow{4}{*}{$\begin{array}{l}\text { Concentration of } \\
\text { IgG }(\mathrm{mg} / \mathrm{l})\end{array}$} & \multicolumn{3}{l}{ Method of IgG purification } \\
\cline { 2 - 4 } & $\begin{array}{l}\text { Ammonium } \\
\text { sulphate } \\
\text { precipitated } \\
(\%)\end{array}$ & $\begin{array}{l}\text { DEAE } \\
\text { cellulose } \\
\text { treated } \\
(\%)\end{array}$ & $\begin{array}{l}\text { Protein A } \\
\text { CL-4B } \\
\text { treated } \\
(\%)\end{array}$ \\
\hline 50 & $31 \pm 10$ & $38 \pm 10$ & $79 \pm 9$ \\
100 & & $111 \pm 13$ & $166 \pm 16$ \\
150 & $137 \pm 6$ & $127 \pm 8$ & $197 \pm 7$ \\
200 & & $192 \pm 15$ & $364 \pm 18$ \\
300 & $318 \pm 12$ & $274 \pm 7$ & $772 \pm 13$ \\
400 &
\end{tabular}

Results expressed as the percentage stimulation compared with that observed with basal (mean $\pm S E M, n=6$ ). Corrected basal counts $545 \mathrm{cpm}$

Table 2. Stimulation of human adipocyte lipogenesis by IgG prepared from lymphocyte cultures and normal human serum

\begin{tabular}{|c|c|c|c|c|}
\hline \multirow[b]{2}{*}{$\begin{array}{l}\text { Concen- } \\
\text { tration } \\
\text { of } \operatorname{IgG} \\
(\mathrm{mg} / \mathrm{l})\end{array}$} & \multicolumn{4}{|c|}{ Stimulation (\%) } \\
\hline & $\begin{array}{l}\text { IgG prepared } \\
\text { from } \\
\text { lymphocyte } \\
\text { culture }\end{array}$ & $\begin{array}{l}\text { Lymphocyte } \\
\text { IgG neutral- } \\
\text { ised with } \\
\gamma \text {-chain anti- } \\
\text { serum }\end{array}$ & $\begin{array}{l}\text { Serum } \\
\text { IgG }\end{array}$ & $\begin{array}{l}\text { Serum IgG } \\
\text { neutralised } \\
\text { with } \gamma \text {-chain } \\
\text { antiserum }\end{array}$ \\
\hline 50 & $158 \pm 10$ & $104 \pm 9^{a}$ & $240 \pm 16$ & $78 \pm 8^{b}$ \\
\hline 100 & $318 \pm 25$ & $120 \pm 10^{b}$ & $282 \pm 10$ & $80 \pm 11^{b}$ \\
\hline 200 & $258 \pm 21$ & $126 \pm 13^{\mathrm{b}}$ & $278 \pm 14$ & $122 \pm 13^{b}$ \\
\hline
\end{tabular}

Results expressed as mean $\pm \mathrm{SEM}, n=6$. Corrected basal counts $545 \mathrm{cpm} .{ }^{\mathrm{a}} p<0.05$; $^{\mathrm{b}} p<0.01$

insulin, and $256 \%$ above basal by $400 \mathrm{mg} / \mathrm{l}$ of human IgG.

Whereas commercially obtained $\gamma$-globulin was markedly stimulatory in a dose-dependent fashion, $\alpha$ and $\beta$ globulins had minimal stimulatory activity, presumably due to $\gamma$-globulin impurities, since chromatography through protein A-sepharose columns eliminated the minimal stimulatory effect of these globulins. Therefore commercial IgG was the most stimulatory of the commercial proteins tested.

Fc fractions of IgG caused a stimulation of lipogenesis of a magnitude similar to that observed with whole IgG preparations. Fab fractions, in contrast, produced minimal or no stimulation (Fig.3). The stimulation produced by Fab fractions was similar in magnitude to that produced by commercial $\alpha$ and $\beta$ globulins, and disappeared following rechromatography over protein Asepharose columns. F(ab) ${ }_{2}$ fractions likewise exerted no stimulatory effect on the adipocyte lipogenesis.

IgG-induced stimulation of adipocyte lipogenesis was neutralised by $\gamma$-chain specific antisera. Figure 4 shows that the degree of neutralisation of $\mathrm{IgG}$ stimulatory activity was proportional to the dose of antiserum added. The stimulatory activity of all IgG samples irrespective of their mode of preparation including that ob-

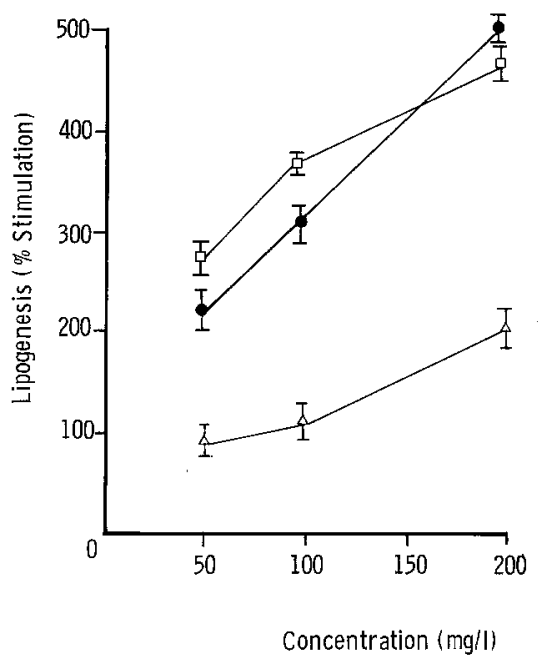

Fig. 3. Insulin-like stimulatory effect of $\operatorname{IgG}$ and its fragments on human adipocyte lipogenesis $\left(50-200 \mathrm{mg} / \mathrm{l}, 4 \times 10^{7}\right.$ cells $\left./ 1\right)$. Key: IgG $\square \mathrm{Fc} ; \triangle \mathrm{Fab}$. Corrected basal counts $107 \mathrm{cpm}$

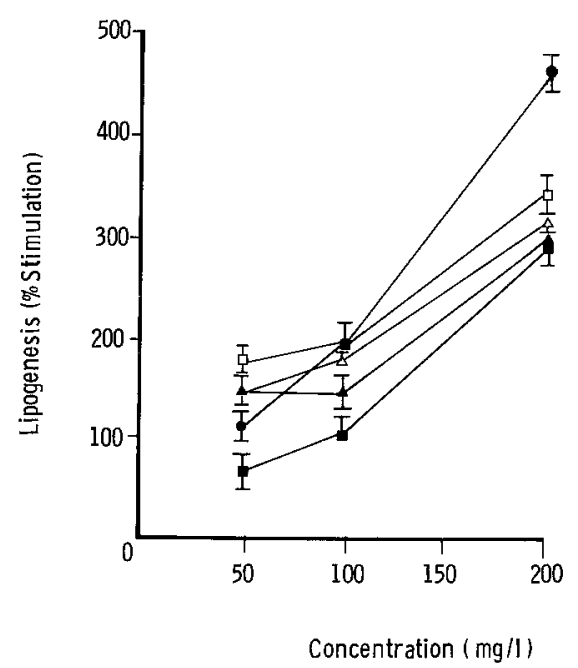

Fig.4. The insulin-like stimulatory effect of human $\operatorname{IgG}(50$ $200 \mathrm{mg} / 1)$ on human adipocyte lipogenesis $\left(4 \times 10^{7}\right.$ cells $\left./ 1\right)$ in the presence and absence of different concentrations of anti-IgG antiserum. $-\quad-\operatorname{IgG} ; \square \square \mathrm{IgG}:$ anti-IgG antiserum $(10: 1) ; \Delta-\Delta$ IgG: anti-IgG antiserum (5:1); $\longrightarrow$ IgG: anti-IgG antiserum (2: 1); IgG: anti-IgG antiserum (1:3). Corrected basal counts $188 \mathrm{cpm}$

tained from lymphocyte cultures, was neutralised by these antisera. Each antiserum had an intrinsic stimulatory effect (presumably due to a high IgG content) which was assayed every time a neutralisation experiment was carried out. Pre-incubation of $\operatorname{IgG}$ and $\mathrm{Fc}$ fractions with anti-IgG antiserum or anti-Fc antiserum neutralised their stimulatory activity. Pre-incubation of IgG and $\mathrm{Fc}$ fractions with anti-Fab antiserum did not produce any significant alteration in the stimulatory activity of these fractions. Concomitent incubation with insulin and $\mathrm{IgG}$ resulted in additive effects, provided submaximal concentrations of insulin $(50 \mathrm{mU} / 1)$ and IgG (50-100 mg/1) were used. 


\section{Discussion}

We were able to obtain consistent dose-response curves at concentrations of insulin between $50-100 \mathrm{mU} / 1$. Only on rare occasions were we able to observe statistically significant stimulation of lipogensis by human adipocytes at $25 \mathrm{mU} / \mathrm{l}$. Previous reports have claimed stimulation over the range 3-6 mU/1, but some of these data have not been supported by rigorous statistical analysis. Our observations are based on assays carried out in sextuplicate, and hence they are amenable to statistical analysis.

Our observations on insulin stimulated lipogenesis differ from the previously published data in another respect: the maximal responsiveness of this system is markedly greater than that reported by other workers in this field. No clear explanation is available to account for this discrepancy. However, it may be relevant that the unstimulated basal incorporation of $\left[\mathrm{U}^{14} \mathrm{C}\right]-\mathrm{D}$-glucose into lipid by adipocytes in our experiments was lower than that reported by others [7] and that our incubations were carried out for $2 \mathrm{~h}$ rather than $90 \mathrm{~min}$, as in the study by Pedersen et al. [7]. Both of these factors would contribute to a greater stimulation of lipogenesis. Our comparatively low basal counts are to some extent the result of the collagenase preparation used. Pedersen et al. [7] used a collagenase preparation obtained from Sigma, which in our hands leads to high basal counts and a diminution in the magnitude of maximal stimulation by insulin.

The mechanism of action of $\operatorname{IgG}$ needs further investigation. However, monoclonal $\mathrm{IgG}$ from myeloma patients and polyclonal IgG from normal subjects had a similar potency. This observation suggested that the non-variable portion of the $\operatorname{IgG}$ molecule, the $\mathrm{Fc}$, was responsible for this effect and this was indeed confirmed by our subsequent experiments demonstrating that: (1) Fc fractions had stimulatory potency similar to those of the parent IgG; (2) anti-Fc sera neutralised the stimulatory effect of both IgG and Fc fractions; and (3) $F a b$ and $F(a b)_{2}$ fractions exerted no effect on adipocyte lipogenesis. Our data thus point to the presence of Fc receptors on adipocyte membranes.

Our work also raises some questions regarding the interpretation of previously published data demonstrating the inhibitory effect of insulin receptor antibodies on insulin binding to adipocytes [10, 11], while at the same time stimulating adipocyte metabolism in vitro [12]. Any IgG preparation from a patient with an autoimmune disease is not likely to contain more than $1 \%$ of the insulin receptor specific antibody; it is hence likely that $99 \%$ of $\mathrm{IgG}$ in any insulin receptor antibody preparation is non-specific IgG. If this is so, the paradoxical stimulatory effect of insulin receptor antibody may be attributed, at least in part, to non-specific IgG, particularly since patients with insulin receptor antibodies may have marked elevations of serum IgG concentrations [14]. However, the insulinomimetic action of insulin re- ceptor antibodies is probably more specific than that of IgG reported in this study since the action of the former has been shown to be mediated through the Fab moiety of the IgG molecule [13] which binds to the insulin receptor. Furthermore, IgG preparations from patients with insulin receptor antibodies lose their Fab mediated stimulatory ability when such patients are in remission $[14,15]$. By contrast, our observations on normal and monoclonal human IgG show that their stimulatory effect is mediated through the Fc moiety. Fab and $F(a b)_{2}$ fractions prepared by us did not exert a significant effect on adipocyte lipogenesis.

The biological significance of the stimulatory effect of human IgG on human adipocytes is unclear. However, the fact that multiple myeloma may be associated with severe lipid abnormalities [16, 17], and that diabetes may occur in association with hypogammaglobulinaemia [18], suggests that the insulin-like stimulatory effect of $\operatorname{IgG}$ may be of relevance to the underlying mechanisms. Finally, the extremely low concentrations at which this effect of human IgG has been observed in our experiments would suggest that it may be of relevance in vivo, bearing in mind two points: (1) that collagenase treated and untreated adipose tissue responds to IgG at concentrations less than $1 \%$ of those found in the plasma and (2) that whole serum/plasma is not markedly stimulatory in the fat cell system [2]. This paradox would indicate that there probably exists a concomitant inhibitor in the serum/plasma in vivo that neutralizes the stimulatory effect of $\mathrm{IgG}$ in vivo. Our initial experiments confirm this (unpublished data).

In terms of pathophysiology, our observations suggest that selective deposition of IgG at inflammatory sites may be the setting where the metabolic effects of IgG become relevant. It is possible that cells other than adipocytes, especially those involved in inflammatory responses, are stimulated by IgG: for example, IgG may stimulate phagocytes and other inflammatory cells into greater metabolic activity. This area requires further investigation.

Acknowlegements This work was supported by the Endowment Fund of the Royal Free Hospital, and by a grant from Eli Lilly \& Co Ltd. The authors thank Professor D.Doniach for encouragement and guidance; and Mrs. P. Dale and Mrs. M. Elleman for secretarial assistance.

\section{References}

1. Khokher MA, Coulston LG, Dandona P(1981) Insulin-like stimulatory effect of normal IgG on lipogenesis. Diabetologia 21: 290-291

2. Khokher MA, Dandona P, Coulston LG, Janah S (1981) Insulin like stimulatory effect of human immunoglobulin $\mathrm{G}$ on adipocyte lipogenesis. Diabetes 30: 1068-1071

3. Khokher MA, Dandona P (1983) Insulin-like stimulatory effect of $\mathrm{Fc}$ fragments of human immunoglobulin $\mathrm{G}$ on rat adipocyte lipogenesis: indirect evidence for $\mathrm{Fc}$ receptors on adipocytes. J Clin Endocrinol Metab 56: 393-396

4. Bywater R (1978) Elution of immunoglobulins from protein A- 
sepharose CL-4B columns. In: Epton R (ed) Chromatography of synthetic and biological polymers. Ellis Harwood, Chichester, UK, pp 337-340

5. Davies ME, Barret AJ, Hembry RM (1978) Preparation of antibody fragments: conditions for proteolysis compared by SDS slab-gel electrophoresis and quantitation of antibody yield. J Immunol Meth 21:305-315

6. Baldwin D, Terris S, Steiner DF (1980) Characterisation of insulin like actions of anti-insulin receptor antibodies. J Biol Chem 255: $4028-4039$

7. Pedersen O, Hjollund E, Beck-Nielsen H, Lindskor HO, Sonne O, Gliemann J (1981) Insulin receptor binding and receptor-mediated insulin degradation in human adipocytes. Diabetologia 20: 636-641

8. Moody AJ, Stan MA, Stan M, Gliemann J (1974) A simple free fat cell bioassay of insulin. Horm Metab Res 6: 12-16

9. Andersen O, Gliemann J, Gammeltoft S (1977) Receptor binding and biological effect of insulin in human adipocytes. Diabetologia 13: $589-593$

10. Flier JS, Kahn CR, Roth J, Bar RS (1976) Antibodies that impair insulin receptor binding in unusual diabetic syndrome with severe insulin resistance. Science 190: 63-65

11. Jacobs S, Chang KJ, Cuatrecasas P (1978) Antibodies to purified insulin receptor have insulin-like activity. Science 200: 1283-1284

12. Kahn CR, Baird K, Flier JS, Jarret DB (1977) Effect of autoantibodies to the insulin receptor on isolated adipocytes - studies of insulin binding and insulin action. J Clin Invest 60: 1094-1099

13. Kahn CR, Baird KL, Jarret DB, Flier IS (1978) Direct demonstration that receptor cross-linking activity of aggregation is important in insulin action. Proc Natl Acad Sci USA 75: 4209-4213
14. Flier JS, Bar RS, Muggeo M, Kahn CR, Roth JM, Forden P (1978) The evolving clinical course of patients with insulin receptor autoantibodies: spontaneous remission or receptor proliferation with hypoglycaemia. J Clin Endocrinol 47: 985-995

15. Kasuga M, Akanuma Y, Tsushima T, Suzuki K, Kosaka K, Kibata $M(1978)$ Effects of anti-insulin receptor antibodies on the metabolism of human adipocytes. Diabetes 27: 938-946

16. Wilson DE, Flowers CM, Hershgold EJ, Eaton RP (1975) Multiple myeloma, cryoglobulinaemia and xanthomatosis. Am J Med 59: $721-729$

17. Miller NE, Levy Y, Turner $\mathbf{P}$, Weight $M$, Rao S, Wing A, Uterman G, Slavin B, Lewis B (1981) Hyperlipoproteinaemia due to impaired intermediate density and low density lipoprotein catabolism in multiple myeloma. Eur J Clin Invest 11:21 (Abstract)

18. Young RJ, Duncan LFP, Paton L, Yap PL (1981) Development of insulin-dependent diabetes in adult-onset hypogammaglobulinaemia. Br Med J 282: 1668

Received: 28 June 1982

and in revised form: 17 June 1983

Dr. P. Dandona

Metabolic Unit

Department of Chemical Pathology

Royal Free Hospital School of Medicine

Pond Street

London NW3 2QG, UK 